УДК 338.47(045)

DOI: https://doi.org/10.37320/2415-3583/12.22

Побережна 3.M.

кандидат економічних наук, доцент,

Наиіональний авіаиійний університет

ORCID: http://orcid.org/0000-0001-6245-038X

\title{
УПРАВЛІННЯ АДАПТИВНІСТЮ БІЗНЕС-МОДЕЛІ АВІАПІДПРИЕМСТВА ДО УМОВ ЗОВНІШНЬОГО СЕРЕДОВИЩА
}

У статті проведено аналіз проблем адаптащії авіапідприємств до умов зовні-инього середовища. Запропоновано напрями адаптаиії бізнес-моделей авіа-підприємств, систематизовано методичні підходи до побудови бізнес-моделі авіапідприємства, серед яких виокремлюють: орієнтований на бізнес-процеси; орієнтований на иінність чи клієнта. Визначено низку факторів зовнішнього і внутрішнього середовища, які впливають на формування конкурентної бізнес-моделі на ринку. Охарактеризовані основні риси для авіапідприємств, які потребують оптимізації та адаптації до змінних ринкових умов зовнішнього середовища. Узагальнено основні підсистеми впливу зовнішнього середовища на авіапідприємство. Запропоновано комплекс заходів для підвищення ефективності управління адаптивністю бізнес-моделі на авіапідприємстві, яка трунтується на управлінських бізнес-процесах задля підвищення ефективності процесу управління та координації рішень.

Ключові слова: бізнес-модель, авіапідприємства, управління адаптивністю, зовнішнє середовище, чинники впливу на бізнес-модель, бізнес-процеси, ефективність бізнес-моделі.

Постановка проблеми. Сучасні технології та постійно зростаюча конку-ренція привели до динамічного розвитку ринку авіаційної галузі в усьому світі. Сьогодні більшість авіапідприємств перетворюються у відкриті компа-нії, які активно взаємодіють із покупцями різними способами (поширення інформації через інтернет, радіо, телебачення чи друковані 3МI, продажі онлайн, встановлення зворотного зв'язку через анкетування, телефонні дзвінки, e-mail-звернення тощо). Важливим інструментом управління, який спрощено описує організацію та функціонування всіх дій, спрямованих на створення цінності авіапідприємства, $\epsilon$ бізнес-модель. Величезний потенціал можливостей, які надає ефективна бізнес-модель авіапідприємства, привертає все більше уваги теоретиків та практиків. Управління адаптивністю бізнес-моделі дає змогу визначити ціннісні уподобання споживачів та знайти способи їх задоволення з метою нарощування цінності самого авіапідприємства. Крім того, як показує досвід, досягнення комерційного успіху найчастіше залежить не від технологічних нововведень, а саме від побудови оптимальної бізнес-моделі та умов адаптації ii під впливом зовнішнього середовища.

Аналіз останніх досліджень і публікацій. Питання, пов'язані 3 розумінням сутності та особливостей функціонування бізнес-моделей, знайшли відображення у працях таких закордонних дослідників, як: Р. Аміт К. Зотт [1], Р. Касадесус-Манасел [2], Дж. Мегрела [3], О. Остервальдер [4], Д. Тісс [5]. Серед українських науковців вагомий внесок у вивчення проблеми адаптації бізнес-моделі підприємства здійснили: О. Ареф’єва, І. Мягких [6], Н. Ревуцька [7], В. Чеглатонєв [8], А. Белов [9], А. Розман [10], Л. Литвиненко [11]. Незважаючи на постійно зростаючий інтерес учених до пошуку шляхів забезпечення адаптивності підприємства в умовах невизначеності та змін, велика кількість проблем із цього питання залишаються нерозв'язаними. Малодослідженими є питання адаптивності бізнес-моделі авіапідприємства до умов зовнішнього середовища. У зв'язку з цим особливої актуальності набуває необхідність розвитку теоретичних положень та практичних рекомендацій щодо способів ефективного управління адаптивністю бізнес-моделі авіапідприємства.

Метою статті $\epsilon$ управління адаптивністю бізнесмоделі авіапідприємства до умов зовнішнього середовища, а також визначення особливостей та перспективних напрямів функціонування авіапідприємств на ринку.

Виклад основного матеріалу. Адаптація до зміни ринкових умов $\epsilon$ вимогою часу для всіх підприємств, зокрема для авіапідприємств, адже передбачає усвідомлення загроз та можливостей зовнішнього середовища (збір та оцінку інформації, аналіз загроз і можливостей, визначення рівня чутливості до цих змін), розроблення адаптаційних заходів із урахуванням усіх аспектів діяльності авіапідприємства та його потенціалу, активну адаптацію (реалізацію заходів щодо адаптації та оцінку їхньої ефективності). Нині під час управління адаптивністю бізнес-моделей авіапідприємства виокремлюють два підходи:

-орієнтований на бізнес-процеси чи ролі (підхід, спрямований всередину авіапідприємства);

- орієнтований на цінність чи клієнта (підхід, спрямований на зовнішнє оточення авіапідприємства).

Перший підхід пов'язаний із розглядом діяльності авіапідприємства 3 погляду бізнес-процесів i технологій (фокус уваги спрямований всередину авіапідприємства).

Другий підхід, навпаки, передбачає орієнтацію на цінність, яку авіапідп-риємство створює для зовнішніх клієнтів, а також на результати його діяль-ності.

Узагальнюючи наявні наукові положення, пропонуємо розглядати адаптаційну бізнес-модель як спрощене відображення механізму ведення певної економічної діяльності, пов'язаної 3 виробництвом продукції (продажем товарів, наданням послуг, виконанням робіт), що $є$ цінною для споживача та забезпечує отримання прибутку. 
Адаптаційна бізнес-модель авіапідприємства - це комплекс елементів внутрішнього середовища, бізнес-операцій та бізнес-функцій перевізника, що забезпечують його успішне функціонування на ринку, 3 можливістю довгострокового розвитку та отримання прибутку, збереження стійкості в кризових ситуаціях, гнучке реагування та адаптацію до змінних умов зовнішнього середовища і $є$ базою під час формування конкурентних переваг авіапідприємства.

Динамічність середовища діяльності підприємств, поява нових технологій та конкуренція зумовлюють застаріння наявних бізнес- моделей, у зв'язку з цим їх регулярна переоцінка повинна стати відпрацьованою практикою. Перегляд бізнес-моделі підприємства здійснюється зазвичай у три етапи:

- аналіз типових моделей бізнесу підприємств у галузі, ключових на-вичок, вмінь кожного типу підприємств і логіки появи цих моделей;

- аналіз поточної бізнес-моделі підприємства і логіки iï появи, дослідження ключових навичок та умінь на підприємстві, виявлення суперечностей наявної моделі;

- вибір перспективної бізнес-моделі з-поміж альтернативних варіантів, опис логіки переходу до перспективної моделі бізнесу, розроблення програми переходу [11].

У процесі управління адаптивністю бізнес-моделі авіапідприємства слід враховувати низку факторів, які впливають на формування конкурентної бізнес-моделі на ринку, таких як:

- виділення найбільш перспективних сегментів ринку та приділення їм окремої уваги;

- усвідомлення етапу життєвого циклу підприємства та окремих видів послуг, які воно надає споживачеві (формування, зростання, зрілість, спад);

- прагнення досягти конкурентної переваги за допомогою чітко визначених важелів (зниження собівартості, збільшення цінності);

- урахування географічних особливостей цільових груп споживачів тощо.

Відзначимо, що формування бізнес-моделі авіаційного підприємства відбувається під впливом низки чинників як зовнішнього, так і внутрішнього середовища.
До групи внутрішніх чинників слід віднести: економічні та соціальні умови; ресурси та комунікації; корпоративні зв'язки; офіційну ринкову політику; професійність персоналу; репутацію компанії; рівень диференціації послуг; стабільність генерування грошового потоку; стиль керівництва; фінансовий стан підприємства.

Чинники впливу зовнішнього середовища на адаптацію авіапідприємст-ва наведені у таблиці 1.

Необхідно наголосити також на важливості врахування у процесі побудови бізнес-моделі особливостей галузі, в якій діє підприємство.

Основними характеристиками для авіапідприємств, які потребують оптимізації та адаптації до змінних ринкових умов зовнішнього середовища, $\epsilon$ :

1. Планування використання повітряних суден (ПС):

- прогнозування показників прибутковості авіакомпанії для забезпечення розроблення відповідних довгострокових рішень у сфері бізнес-планування, які передбачають визначення цільових ринків та частоти перевезень;

- формування моделей розподілу парку ПС для планування використання ПС та максимізації прибутку;

- розроблення моделей маршрутизації ПС авіакомпанії для оперативного управління розподілом ПС на мережі;

- оптимізація співпраці у межах код-шерінгу, націлена на збільшення доходів за рахунок налагодження партнерських відносин між авіакомпаніями.

2. Планування екіпажу:

- розроблення моделей для ефективного планування перевезень та місячних розкладів льотного екіпажу;

- планування кадрових моделей щодо льотного екіпажу для прийняття ком-плексних рішень у питаннях чисельності персоналу, рівнів навчання, надан-ня відпусток та розподілу екіпажу за географічно розмежованими базами.

3. Управління доходами:

- формування моделей оптимізації доходів, що сфокусовані на обліку надходжень, ціноутворенні та отриманні вигоди;

- використання прогнозування попиту, засноване на концепції O \& D («походження - місце при-

Таблиця 1 - Чинники впливу зовнішнього середовища на бізнес-модель авіапідприємства

\begin{tabular}{|l|l|l|}
\hline \multicolumn{1}{|c|}{ Чинники прямої дії } & \multicolumn{1}{|c|}{ Напрям впливу } & \multicolumn{1}{|c|}{ Чинники непрямої дії } \\
\hline $\begin{array}{l}\text { Закони та підзаконні акти, що регламентують } \\
\text { діяльність підприємств; арбітраж; нетарифні } \\
\text { бар'єри }\end{array}$ & Політико-правовий & $\begin{array}{l}\text { Загальний законодавчий простір для } \\
\text { товаровиробників; політичний клімат у країні; } \\
\text { групи тиску; неформальне втручання уряду; } \\
\text { суспільно-політичний устрій; ідеологія }\end{array}$ \\
\hline $\begin{array}{l}\text { Рівень розвитку ринкових відносин; система } \\
\text { оподаткування; фіскальна політика; обсяги } \\
\text { інвестицій у промисловість; установлення } \\
\text { пільг; структура попиту та пропозиції на ринку }\end{array}$ & Економічний & $\begin{array}{l}\text { Стан економіки; платіжний баланс країни; } \\
\text { ринкові стратегії підприємств-конкурентів, } \\
\text { привабливість країни щодо експорту своїх } \\
\text { товарів }\end{array}$ \\
\hline $\begin{array}{l}\text { Система освіти, підвищення кваліфікації та } \\
\text { управління кадрами, неформальні групи }\end{array}$ & Соціально-культурний & $\begin{array}{l}\text { Національні інтереси; соціальні інститути; } \\
\text { цінності та відношення до праці, успіху, змін, } \\
\text { ризику та ін. }\end{array}$ \\
\hline $\begin{array}{l}\text { Нові інформаційні технології; рівень } \\
\text { технічного розвитк конкуруючих } \\
\text { підприємств; маркетингова орієнтація } \\
\text { конкурентів }\end{array}$ & $\begin{array}{l}\text { Рівень інноваційної активності та } \\
\text { інформаційного забезпечення конкурентів } \\
\text { у сфері промисловості; науково-технічний } \\
\text { прогрес; розвиток галузевої науки }\end{array}$ \\
\hline $\begin{array}{l}\text { Обмеження нанесення шкоди навколишньому } \\
\text { середовищу }\end{array}$ & Екологічний & $\begin{array}{l}\text { Ступінь активізації діяльності зі збереження } \\
\text { ресурсів і захисту навколишнього середовища }\end{array}$ \\
\hline
\end{tabular}


значення»), для обгрунтування управлінських рішень щодо моделей оптимізації доходів;

- розроблення моделі управління доходами нового покоління для більш ефективної конкурентної боротьби із зростаючою кількістю лоукост-перевізників, бізнесстратегії яких суттєво відрізняються та є значно спрощеними порівняно із звичайними авіакомпаніями [12].

Успішність діяльності авіапідприємств визначається правильністю ви-бору бізнес-моделі при адаптації до умов зовнішнього середовища. При цьому необхідно забезпечити життєздатність бізнес-моделі, поєднання внутрішніх факторів та адаптацію до мінливих умов зовнішнього середовища. Основні підсистеми впливу зовнішнього середовища на авіапідприємство зображено на рис. 1 .

Запровадження адаптаційних заходів у розрізі формування оптимальної бізнес-моделі авіапідприємства передбачає створення інтегрованих моделей оцінки наявних ресурсів, оцінювання рівня ризиків, адаптацію стратегій, планів, політик до змін, моніторинг факторів мікро-, мезо- та макросередовища.

До основних вимог, які, на нашу думку, повинні ставитися до бізнес-моделі в системі управління адаптивністю авіапідприємства, можна віднести:

- орієнтацію на досягнення цілей підприємства;

- досягнення балансу між встановленням цінності для споживача та вартістю підприємства;

- чітке встановлення та розуміння, вміння застосовувати набір страте-гій;

- ієрархічність обраних та діючих стратегій, адже можна виділити загальну стратегію, продуктовотоварні стратегії окремих підрозділів, основні та забезпечувальні стратегії (ресурсні та функціональні) для кожного із ланцюгів;

- гнучкість і динамічність бізнес-моделі, тобто, враховуючи зміни в зовнішньому та внутрішньому середовищі, здійснювати аналіз та підлаштування, зміну пріоритетів та змісту, перехід на резервні стратегії. Одним із пріоритетів вибору оптимальної бізнесмоделі є вибір способу формування цінності для споживача. Основними векторами формування цінності для споживачів авіапідприємств є: товарне лідерство, операційна досконалість та розуміння (близькість до) клієнта (рис. 2).

Для ефективного впровадження адаптивності бізнес-моделі до умов зовнішнього середовища в системі управління авіапідприємством пропонуємо здійснити комплекс заходів, які грунтуються на управлінських бізнес-процесах задля підвищення ефективності процесу управління та координації рішень. Адже саме управлінські бізнес-процеси повинні бути зорієнтовані на виконання завдань, наведених в табл. 2 .

У мінливих ситуаціях сьогодення забезпечення ефективного функціонування господарюючих суб'єктів стає можливим завдяки формуванню адаптивності бізнес-моделі в системі управління конкурентоспроможністю підприємства. Адже одним з основних чинників забезпечення ефективності діяльності підприємства та підвищення рівня його конкурентоспроможності $\epsilon$ його здатність до ефективного управління адаптивністю бізнес-моделі до умов зовнішнього середовища.

Висновки. Проведені дослідження дали змогу дійти висновку, що в умовах загострення конкуренції в низці секторів економіки, негативного впливу світової фінансово-економічної кризи на підприємства швидкість пристосування підприємств до факторів середовища суттєво збільшилася. Сучасним підприємствам для успішної адаптації бізнес-моделі до змінних ринкових умов необхідно відстежувати зміни у політиці конкурентів і поведінці споживачів та адекватно на них реагувати. Авіапідприємствам, які прагнуть вижити на ринку або завоювати більшу ринкову

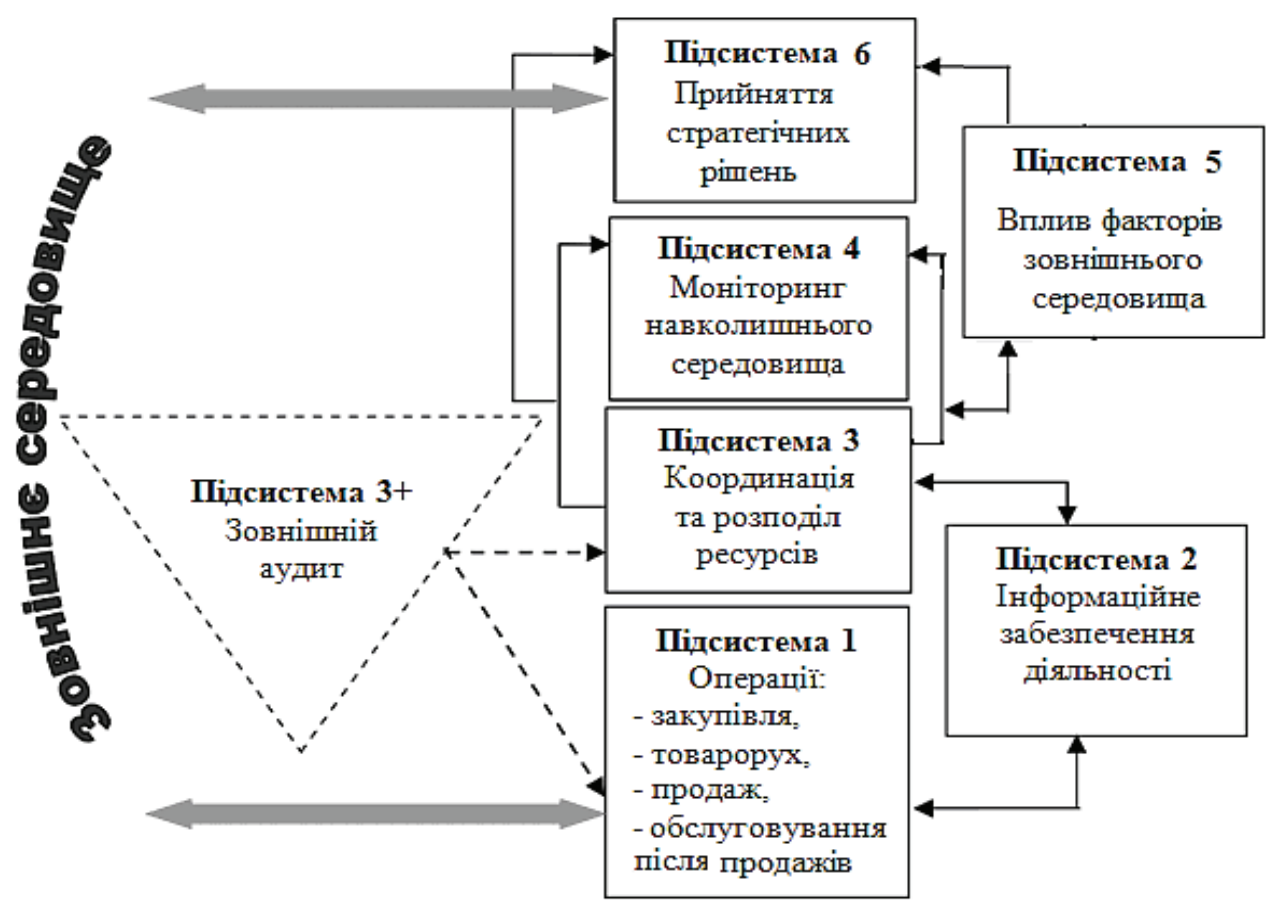

Рисунок 1 - Складники життєздатності бізнес-моделі авіапідприємств 
частку, необхідно пристосовувати свої бізнес-моделі до умов глобального конкурентного середовища. Перспективними напрямами подальших досліджень $\epsilon$ формування механізму адаптації вітчизняних авіа- підприємств до умов зовнішнього середовища та обгрунтування ефективності адаптаційних заходів із використанням інструментарію математичного моделювання.

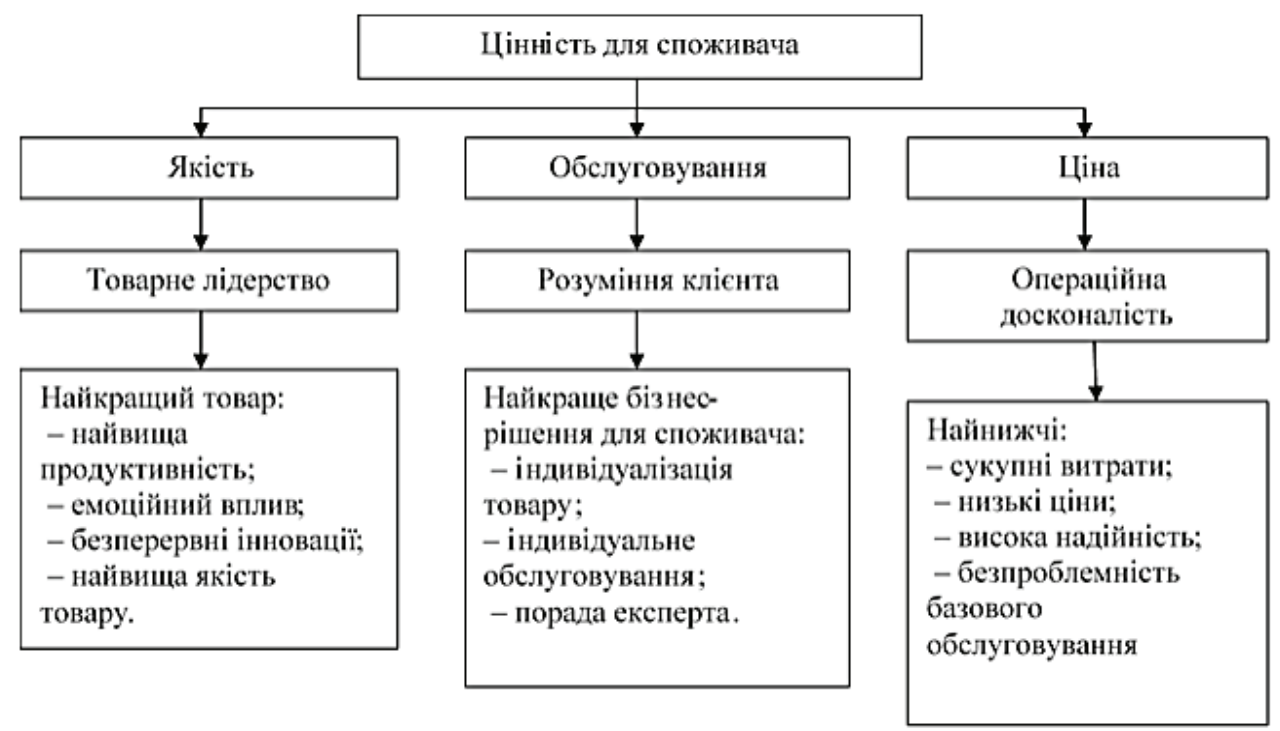

Рисунок 2 - Вектори формування цінності для споживачів авіапідприємств

Таблиця 2 - Комплекс заходів для підвищення ефективності управління адаптивністю бізнес-моделі на авіапідприсмстві

\begin{tabular}{|c|c|c|}
\hline № & Управлінські бізнес-процеси & Комплекс заходів \\
\hline 1. & $\begin{array}{c}\text { Реалізація місії та стратегії } \\
\text { підприємства }\end{array}$ & $\begin{array}{l}\text { - вдосконалення місії та стратегї діяльності підприємства; } \\
\text { - } \text { інформування працівників про місію та стратегію; } \\
\text { - урізноманітнення джерел поширення інформації про місію та стратегію } \\
\text { працівників, партнерів, споживачів (створення сучасного сайту, реклама та ін.). }\end{array}$ \\
\hline 2. & $\begin{array}{c}\text { Реалізація заходів кадрової } \\
\text { політики }\end{array}$ & $\begin{array}{l}\text { - використання різних способів підготовки робочих кадрів (дистанційне } \\
\text { навчання); } \\
\text { - систематичне підвищення кваліфікації інженерно- технічних працівників; } \\
\text { - розроблення заходів щодо залучення й відбору персоналу. }\end{array}$ \\
\hline 3. & $\begin{array}{c}\text { Налагодження зовнішніх та } \\
\text { внутрішніх відносин підприємства }\end{array}$ & $\begin{array}{l}\text { - } \text { налагодження довгострокових контактів із партнерами; } \\
\text { - систематичне проведення маркетингових досліджень; } \\
\text { - проведення святкових загальнокорпоративних заходів; } \\
\text { - запровадження системи матеріального стимулювання працівників до } \\
\text { інноваційної діяльності; } \\
\text { - участь у наукових конференціях, виставках; } \\
\text { - співпраця з інститутами, спільні наукові дослідження, публікації. }\end{array}$ \\
\hline
\end{tabular}

Список використаних джерел:

1. R. Amit, Zott C. (2010). Business Model Design: An Activity System Perspective. Long Range Planning. № 43 (2/3). P. $216-226$. 2. Casadesus-Masanell R. (2010). From Strategy to Business Models and onto Tactics. Long Range Planning. № 43 (92/30). P. $195-215$.

3. Magretta J. (2002). Why Business Models Matter. Harvard Business Review. № 80 (5). P. 86-92.

4. Osterwalder A. (2010). Business Model Generation. Hoboken, New Jersey: John Wiley \& Sons, Inc, 282 p.

5. Teece D. J. (2010). Business Models, Business Strategy and Innovation. Long Range Planning. № 43 (2/3). P. $172-194$.

6. Ареф'єва О.В., Мягких І.М. Проблеми формування бізнес-моделі авіакомпанії в ринкових умовах. Формування ринкових відносин в Україні. 2013. № 9. С. 91-94.

7. Ревуцька Н. В. Формування бізнес-моделі підприємства: дис. на здобуття наук. ступеня канд. екон. наук: 08.06.01. К.: KHEУ, 2005. 259 c.

8. Чеглатонєв В. І. Споживча цінність як основа бізнес-моделі оператора стільникового зв'язку. Вісник Хмельницького національного університету. 2009. № 3 (т. 1). С. 223-227.

9. Белов А. В поисках гармоничной бизнес-модели. URL: http://www.altrc.ru/library/22/1008. (дата звернення: 21.05.2020)

10. Розман А. Бізнес-модель підприємства роздрібної торгівлі. Вісник КНТЕУ. 2014. № 3. С. 15-34.

11. Литвиненко Л. Адаптація бізнес-моделі авіакомпанії до умов глобального конкурентного середовища. Економічний аналіз. Тернопіль. 2011. № 8. Ч 2. С. 233-237. 


\section{References:}

1. R. Amit, Zott C. (2010). Business Model Design: An Activity System Perspective. Long Range Planning. № 43 (2/3). pp. 216-226.

2. Casadesus-Masanell R. (2010). From Strategy to Business Models and onto Tactics. Long Range Planning. № 43 (92/30). pp. 195-215.

3. Magretta J. (2002). Why Business Models Matter. Harvard Business Review. № 80 (5). pp. 86-92.

4. Osterwalder A. (2010). Business Model Generation. Hoboken, New Jersey: John Wiley \& Sons, Inc, $282 \mathrm{p}$

5. Teece D. J. (2010). Business Models, Business Strategy and Innovation. Long Range Planning. № 43 (2/3). pp. 172-194.

6. Arefieva O.V., Myagkyh I. M. (2013). Problemy formuvannya business-modeli aviakompaniyi v rynkovih umovah [Problems of forming an airline business model in market conditions]. Formuvannya rynkovikh vidnosyn v Ukrainy. № 9. pp. 91-94.

7. Revytska N.V. (2005). Formuvannya business modeli pidpryemstva [Formation of business model of the enterprise]: dis. for science. degree of cand. econ. science: 08.06.01. K.: KNEU. 259 p.

8. Cheglatonev V.I. (2009). Spozhivcha tsinnist yak osnova business-modeli operatora stilnykovogo zviazku [Consumer value as the basis of a cellular operator's business model]. Vistnyk Khmelnytskogo natsionalnogo universytety. № 3 (т. 1). pp. $223-227$.

9. Belov A. V poiskah garmonichnoy business modeli [In search of a harmonious business model]. URL: http://www.altrc.ru/ library/22/1008. (accessed 21 May 2020).

10. Rozman A. (2014). Busines model pidpryemstva rozdribnoyi torgivli [Business model of a retail business]. Vistnyk KNEU. № 3. pp. 15-34.

11. Lytvynenko L. (2011). Adaptatsia business modeli aviakompaniyi do umov globalnogo konkurentnogo seredovysha [Adaptation of the airline's business model to the conditions of the global competitive environment]. Ekonomichnyi analiz. Ternopil. № 8 . P 2. pp. 233-237.

Poberezhna Zarina

National Aviation University

\section{MANAGEMENT OF ADAPTIVITY OF THE BUSINESS MODEL OF THE AVIATION ENTERPRISE TO THE CONDITIONS OF THE EXTERNAL ENVIRONMENT}

The article analyzes the problems of adaptation of airlines to environmental conditions. The directions of adaptation of business models of the airlines are of-fered, the methodical approaches to construction of the business model of the air company are systematized, among which are distinguished: focused on business processes; value-oriented / customer-oriented. A number of environmental factors have been identified: social; natural; economic; culturological; political; legal; sci-entific and technical; development of market relations and commercial infrastruc-ture; development of investment infrastructure; the likelihood of martial law in the country; perfection of legislative and judicial power; level of government corruption. As well as factors of the internal environment: economic and social conditions; resources and communications; corporate relations; official market policy; professionalism of staff; the company's reputation; level of service differentiation; stability of cash flow generation; leadership style; the financial condition of the enterprise, which affect the formation of a competitive business model in the market. The main features for airlines that need to be optimized and adapted to changing market conditions of the external environment are described, which are divided into: aircraft use planning, crew planning, revenue management. The main subsystems of the influence of the external environment on the airline are generalized. One of the priorities of choosing the optimal business model is to choose the method of creating value for the consumer. The main vectors of value formation for consumers of airlines are: product leadership, operational excellence and understanding (closeness) to the customer. A set of measures for improving the efficiency of business model adaptability management at the airline, which is based on management business processes to improve the efficiency of the management process and coordination of decisions. The author determined that one of the main factors to ensure the efficiency of the enterprise and increase its level of competitiveness is its ability to effectively manage the adaptability of the business model to environmental conditions.

Key words: business model, airlines, adaptability management, external environment, factors influencing the business model, business processes, business model efficiency.

JEL classifacation: L93, M21, M31, F200 